\title{
ПРАКТИЧНА ЗНАЧУЩІСТЬ ЦИФРОВИХ ТЕХНОЛОГІЙ ДЛЯ ІНТЕЛЕКТУАЛЬНОГО РОЗВИТКУ МАЙБУТНІХ ЛІКАРІВ-СТОМАТОЛОГІВ
}

\author{
Ю. С. Славінська
}

аспірантка кафедри загальної педагогіки і педагогіки вищої школи,

Харківський національний університет імені Г. С. Сковороди

Сьогоденні цифрові технології стали базою для створення нових продуктів, цінностей, властивостей та, відповідно, основою отримання конкурентних переваг на освітньому ринку. Відбувається «цифровий перехід» від свого роду «аналогових» систем і процесів індустріальної економіки та інформаційного суспільства до «цифрової» економіки та «цифрового» суспільства. Рушійною силою цифрової економіки є людський капітал - тобто знання, таланти, навички, вміння, досвід, інтелект людей.

3 метою інтеграції у світові процеси у 2016 році Кабінет Міністрів України презентував проект «Цифровий порядок денний України до 2020 року» («Digital Agenda for Ukraine 2020»), а 17 січня 2018 року на засіданні Уряду було схвалено Концепцію та План дій розвитку цифрової економіки в Україні до 2020 року. Документ визначає ключові політики, першочергові сфери, ініціативи та проекти «цифровізації» України на найближчі 3 роки: розвиток цифрової інфраструктури - широкосмуговий інтернет має бути по всій території України; цифровізація освітніх процесів і стимулювання цифрових трансформацій у системі освіти, медицині, екології, безготівковій економіці, інфраструктурі, громадській безпеці, на транспорті тощо [1].

Стрімке розповсюдження «цифрових» технологій робить цифрові навички тих, хто навчається, ключовими серед інших навичок. Уміння працювати із «цифровими» технологіями поступово стає постійним і необхідним для майбутніх фахівців, у тому числі лікарів-стоматологів. Завданням медичної стоматологічної освіти є підготовка фахівця, здатного розв'язувати складні задачі та проблеми у сфері стоматології та охорони здоров'я або у процесі навчання та виконувати професійну діяльність лікаря-стоматолога [2].

Життя та здоров'я пацієнта мають бути основними людськими та професійними цінностями майбутнього лікаря-стоматолога. Якісна медична допомога неможлива без зміни культурної парадигми та створення нового професійного середовища на базі нових інформаційно-комп'ютерних технологій (IКТ).

Динамічний розвиток IКТ, впровадження концепції навчання «протягом життя», орієнтація на використання мобільних пристроїв у навчальній та професійній діяльності змінюють інформаційний простір закладів вищої освіти (ЗВО). 3 огляду на це використання IКТ у закладах вищої медичної освіти (ЗВМО), зокрема на факультетах стоматології, $\epsilon$ важливою складовою успішного навчання студентів, їх інтелектуального розвитку.

Розвиток ІКТ та їх використання в освітніх методиках на сучасному етапі розвитку суспільства розглядають такі зарубіжні і вітчизняні науковці, як: В. Биков (мобільно орієнтоване середовище, відкрита освіта), Р. Гуревич (сучасні інформаційні технології та інноваційні методики навчання), М. Кадемія, М. Козяр, Н. Кройг, С. Сисоєва, О. Спірін, Є. Полат (інтеграція сучасних освітніх та ІКТ та їх вплив на формування професійних компетенцій, підготовку фахівців з новим типом мислення), В. Поляков (формування інформаційного освітнього середовища). Питання формування інформаційно-комунікативної компетентності майбутніх лікарів досліджувалося науковцями А. Добровольською (концептуальна модель формування IT-компетентності майбутніх лікарів і провізорів у процесі вивчення дисциплін природничо-наукової підготовки), С. Мисловською (основні напрями використання ІКТ у медичній освіті), Л. Войтенко, Н. Лобач, Г. Мороховець, М. Мруга, У. Василишиним (методологічні аспекти формування інформаційної культури як необхідної умови формування компетентності лікаря-інтерна) та іншими.

Незважаючи на посилену увагу науковців до проблеми використання ІКТ у професійній підготовці фахівців, залишається низка важливих для теорії й практики професійної освіти питань.

Метою цією статті є висвітлення практичної значущості цифрових технологій для інтелектуального розвитку майбутніх лікарів-стоматологів.

У стандарті вищої освіти за спеціальністю 221 «Стоматологія» в галузі знань «Охорона здоров’я» перелічені загальні компетентності майбутнього лікаря-стоматолога: здатність до абстрактного мислення, аналізу та синтезу, знання та розуміння предметної області та розуміння професійної діяльності, здатність застосовувати знання у практичній діяльності, навички використання IКТ, здатність до пошуку, опрацювання та аналізу інформації з різних джерел, здатність до адаптації та дії в новій ситуації, вміння виявляти, ставити та вирішувати проблеми, здатність бути критичним і самокритичним, здатність працювати в команді. Особливе місце серед перелічених компетентностей посідають інформаційні та комунікаційні технології. ІКТ сьогодні $€$ засобом розвитку інтелектуальних і творчих здібностей студентів, являють собою потужний інструмент мотивації і розвитку особистості тих, хто навчається. 
Одним з видів навчальної діяльності у ЗВМО є лекція, яка спрямована на первинне оволодіння знаннями. Лекція забезпечує теоретичну основу навчання, розвиває інтерес до навчальної діяльності і конкретної навчальної дисципліни, формує у студентів орієнтири для самостійної роботи над курсом. Застосування викладачами мультимедійних лекцій для викладення теоретичного матеріалу дозволяє змінити способи передачі навчального матеріалу, які традиційно здійснюються під час лекції. У мультимедійних лекціях крім статистичних слайдів, на яких подано різні форми демонстрації (текст, фотографії, схеми, рисунки тощо) додаються фрагменти відеофільмів, які включають, наприклад, клінічні випадки, практичну демонстрацію опрацювання дії на фантомі з докладними покроковими коментарями, стоматологічні операції та інше. Фактичний матеріал мультимедійної лекції складається із досягнень і досвіду світової, вітчизняної медицини, особистого досвіду лектора, кафедри і базового лікувального закладу та включає різноманітні джерела інформації і бази даних: електронні журнали зі стоматології, архіви наукових конференцій, медичні бази даних досліджень, обговорення клінічних випадків, довідкових баз з лікарських препаратів, знайомство $з$ діагностичною і терапевтичною інформацією та новітнім стоматологічним обладнанням тощо.

Студенти крім аудиторних лекцій мають можливість самостійно вивчати матеріал з теми, використовуючи відео-лекції, які розміщені на професійних стоматологічних порталах та на YouTube у мережі Інтернет. Так, на українському навчальному порталі «Навчальний центр Апполонія» подано велику кількість відеолекцій провідних стоматологів України, а саме: Станіслава Гераніна «Філософія ендодонтичного лікування» з відео-демонстраціями всіх етапів ендодонтичного лікування, майстер-класи кращих стоматологів України, клінічний курс з художньої реставрації зубів, інтенсивний фантомний тренінг про білу естетику в реставрації зубів тощо [3]. У такому випадку, крім підвищення наочності мультимедійна лекція сприяє створенню такої емоційної атмосфери, яка пробуджує у студентів інтерес до об'єкта вивчення, заохочує процес пізнання, створюючи належні умови підвищення ефективності розумової діяльності студентів і формування професійних умінь і навичок.

Особливістю викладання дисциплін для студентів-стоматологів $є$ наявність великої кількості практичних навичок, як клінічних, так і лабораторних (технічних), які мають бути опрацьовані на практичних заняттях для кращого сприйняття матеріалу. Тому на практичних заняттях широко впроваджуються різноманітні моделі, муляжі, тренажери, віртуальні симулятори та інші технічні засоби навчання, які дозволяють тією чи іншою мірою достовірності моделювати процеси, ситуації та інші аспекти професійної діяльності медичних працівників: планування лікування зубів, моделювання форми зуба, діагностика захворювань зуба по фото, рентгенівським знімкам, відео тощо.

Максимальну наближеність до реальних умов роботи лікаря з абсолютною безпекою для здоров'я пацієнта можна відтворити за допомогою спеціальних тренажерів-симуляторів у вигляді робочого місця лікарястоматолога, які мають робочий блок, що імітує стоматологічну установку та дозволяє підключати модель голови для проведення опрацювання клінічних навичок, зокрема препарування зубів та ін. Ці тренажери-симулятори зазвичай мають комп'ютерне оснащення та можливість запису, що дозволяє проводити роботу над помилками і повторювати клінічні етапи до досягнення успіху та формування професійних навичок.

Одним із перспективних напрямків вирішення практичних завдань в стоматології є застосування методів комп’ютерного моделювання, CAD/CAM технології та комп’ютерної навігації, наприклад при проведенні реконструктивно-відновних втручань на щелепнолицевій ділянці. Комп'ютерне моделювання в щелепнолицевій хірургії базується на дослідженні віртуальних тривимірних моделей кісток і м'яких тканин, побудованих за даними спіральної або конусної комп’ютерної томографії (КТ) з високою роздільною здатністю. Сучасні програмні комплекси для аналізу томографічних зображень дозволяють візуалізувати внутрішні анатомічні структури, оцінити їх розміри і взаємне розташування, детально вивчити їх морфологічні особливості та навіть деякі фізіологічні характеристики. Важливо зазначити, що отримані зображення (віртуальні моделі) мають дуже високий ступінь роздільної здатності і дозволяють диференціювати тканини із мінімальними структурними відмінностями, вивчати як кісткові, так і м'які тканинні структури, а також є основою для впровадження сучасних систем автоматизованого проектування (CAD/CAM технологія) у клінічну практику [4]. При такому навчанні студенту надається можливість не тільки опрацьовувати навички, допускати і виправляти помилки, але й аналізувати ситуацію і робити висновки. Нині найбільшою проблемою при викладанні клінічної дисципліни $є$ відсутність в клініці індивідуальної забезпеченості студентів тематичними пацієнтами. Тож такі тренажери-симулятори дозволяють планувати навчальний процес незалежно від наявності або відсутності пацієнтів на занятті [5]. До переваг симуляційного тренінгу належать:

- клінічний досвід у віртуальному середовищі без ризику для пацієнта;

- знижений стрес під час перших самостійних маніпуляцій;

- необмежена кількість повторів для опрацювань навичок;

- опрацювання дій при рідкісних патологіях та таких, що загрожують життю; 
- частину функцій викладача бере на себе віртуальний тренажер;

- розвиток як індивідуальних умінь і навичок, так і здатності командної взаємодії;

- об’єктивне оцінювання досягнутого рівня майстерності [6].

На основі сучасних інформаційних технологій створюються системи дистанційного навчання (Моодlе, Claronline, ATutor, SharePointLMS, Live@EDU та ін.). Студент отримує персональний доступ до такої системи, який забезпечує йому можливість користуватися у будь-який зручний для нього час поданими і розміщеними навчальними матеріалами у різних форматах (текст, аудіо, відео, посилання на навчальні ресурси, комп'ютерні тести). Водночас він отримує сервіси для комунікації (чат, форум, глосарій) з іншими студентами, викладачами, фахівцями-стоматологами. Використання дистанційних навчальних курсів дозволяє викладачеві: стандартизувати навчальний контент, організовувати та управляти навчально-пізнавальною діяльністю студентів, індивідуалізувати навчання; студентам дає можливість: звертатися до багатьох джерел навчальної інформації, займатися у зручний для них час, зручному місці й темпі, витрачати більше зусиль і часу на складні та важливі для нього теми 3 метою поглибленого опрацювання, збільшувати його творчий та інтелектуальний потенціал за рахунок самоорганізації, прагнення до знань, уміння володіти IКТ і самостійно приймати відповідальні рішення.

Популярним, доступним та ефективним способом отримання доступу до навчання у найкращих світових ЗВО є масові он-лайн курси (Massive open online courses - MOOC). На сьогоднішній день є безліч платформ MOOC: www.futurelearn.com, www.edx.org, www.novoed.com, www.coursera.org тощо, серед яких є і український аналог - www.prometheus.org.ua. Доступ до матеріалів курсу в більшості платформ є безкоштовним. Після запису на курс можна прослухати всі лекції, попрактикуватись у виконанні певних завдань та за додаткову оплату отримати сертифікат про свої здобутки та підвищити престиж свого резюме. У широкому переліку курсів, що запускаються мало не щодня, можна знайти ті, що відповідають тематиці різних галузей медицини - від теоретичних дисциплін (анатомія, фізіологія, гістологія, громадське здоров'я) до різних практичних напрямків (анестезіологія, невідкладні стани, психіатрія тощо). Таким чином, он-лайн курси - це не тільки можливість поглибити свої знання та покращати свою професійну майстерність, гарний інструмент комунікації $з$ фахівцями різних галузей в усьому світі, це також перспективний шлях розвитку та осучаснення медичної освіти.

3 метою наближення змісту та рівня української медичної додипломної та післядипломної освіти до міжнародних стандартів підготовки лікарів було вирішено включити американські комп'ютерні тести щодо оцінювання студентів та інтернів.

Проведення такого оцінювання дозволяє виявити та озвучити проблеми, наявні в навчальних програмах ЗВО, i, відповідно, змінити або покращити освітню програму підготовки з урахуванням міжнародних вимог та проаналізованих проблемних моментів. Тести мають стоматологічну спрямованість, допомагають розвинути клінічне мислення і застосувати отримані знання з гістології, цитології, ембріології в практичній діяльності лікаря-стоматолога.

Міжнародний досвід показує, що одним із кращих і перспективних способів підвищення рівня медичного обслуговування, розширення можливостей щодо доступності та якості медичних послуг населенню $є$ впровадження телемедицини. До телемедичних послуг належать дистанційні медичні консультації, консиліуми, контроль фізіологічних параметрів організму пацієнта, проведення діагностичних і лікувальних маніпуляцій, обмін результатами обстеження пацієнта, інші медичні послуги, а також медичні відео-конференції, відео семінари, відео-лекції, що здійснюються у вигляді обміну електронними повідомленнями 3 використанням телекомунікацій. Це дає підстави говорити про необхідність широкого застосування сучасних мережевих технологій у навчально-виховному процесі закладів медичної освіти.

Мережеві технології особливо важливі, оскільки вони уможливлюють безпрецедентне різноманіття нових i «відкритих» форматів для поширення інформації. Інформація стає головним джерелом конкурентоспроможності сучасного лікаря-стоматолога (стоматологічні журнали, конгреси, симпозіуми, конференції, форуми, виставки, салони, майстер-класи, курси, семінари, лекції та інші стоматологічні заходи, блоги, вікі). Збір, опис, зберігання та оброблення мережевих даних дозволяє отримувати цінну інформацію для використання в навчальному процесі та професійній діяльності. Уміння працювати з інформацією та їі аналізувати - це можливість першим отримувати цінні професійні «інсайти», тобто бути більш конкурентоспроможним.

Лікарі-стоматологи для навчання, обміну досвідом, постановки діагнозу або проведення консультацій використовують відео-конференції (синхронні та асинхронні). У межах навчального процесу доцільно використовувати вебінари або веб-семінари — on-line заходи, що проходять у мережі Інтернет, в процесі якого кожен учасник може перебувати на своєму робочому місці за комп’ютером. Вебінари дозволяють проводити онлайн-презентації, зустрічі, тренінги, синхронно переглядати сайти, відео-файли і зображення, спільно працювати $з$ документами і додатками (Word, Excel). У вебінарі можуть брати участь від одного до декількох сотень студентів (та інших учасників), з них один або кілька виступають в ролі ведучих вебінару. Вебінари можуть бути спільними і містити 
в себе сеанси голосувань і опитувань, що забезпечує повну взаємодію між студентами і ведучим. Використання вебінару у навчальному процесі дозволяє студентам розвивати та освоювати нові знання й уміння; спілкуватися 3 викладачем або з професійними фахівцями; обговорювати проблемні питання у режимі реального часу у групі студентів; показувати на екрані різні форми демонстрації додаткового матеріалу; знімати психологічні бар'єри, пов'язані з публічністю процесу навчання, сприяти глибокому зануренню у процес навчання, досягненню ефективних результатів, а також не прив'язують учасників вебінару до певних часових рамок.

Велику роль на шляху реформування, а саме щодо регулювання розвитку стоматологічної галузі, відіграють професійні віртуальні об'єднання лікарів-стоматологів. Вони дуже популярні у мережі Інтернет і $є$ авторитетними джерелами для професійного розвитку як студентів, так і професійних лікарів-стоматологів. Основні завдання професійних об'єднань - підтримувати один одного у професійній діяльності та створювати комфортні умови праці для кожного лікаря-стоматолога. Всі об'єднання мають свої інформаційні ресурси у мережі Інтернет: веб-сайти, сторінки у соціальних мережах (Telegram, FaceBook, LinkedIn, MySpace), веб-сервіс Instagram, професійні блоги стоматологів та інші. Використання мережевих ресурсів професійних віртуальних об'єднань лікарів-стоматологів сприяє появі нових можливостей для пізнання, таким чином збільшуючи потенціал студентів, здатних самореалізуватися.

Уведення інформаційних технологій у повсякденну практику лікарів-стоматологів приводить до корінних змін в організації їх праці. Для повсякденної роботи лікаря-стоматолога та медичного персоналу, контролю якості медичної допомоги, аналізу поточної лікувально-профілактичної роботи, обліку пацієнтів, моніторингу показників стану здоров’я пацієнтів у стоматологічних поліклініках впроваджуються медичні інформаційні системи. Ці системи зберігають, обробляють і керують великою кількістю різних даних. Зростаюча доступність електронних даних дає студентам-стоматологам і практикуючим лікарям більш широкі можливості для повторного використання клінічних даних для досліджень і підвищення якості лікування пацієнтів.

Аналіз практичної значущості цифрових технологій для інтелектуального розвитку майбутніх лікарівстоматологів показав, що одна з основних тенденцій, яка визначає сучасного лікаря-стоматолога, пов'язана 3 цифровізацією, технологізацією практичної медицини та медичної науки. У стоматологічній вищій освіти ІКТ використовуються у навчанні, викладанні, самостійній роботі студентів-стоматологів. Використання ІКТ у освітньому процесі дозволяє змінювати характер навчальної діяльності студентів-стоматологів, урізноманітнювати, активізувати їх самостійну роботу, підвищувати інтерес до їх використання, формувати навички професійного (клінічного) мислення, інтелектуальну готовність сприймати аналізовані проблеми, навички самостійно поповнювати свої знання і професійно розвиватися.

Таким чином, підвищення якості підготовки студентів для успішної професійної діяльності в умовах європейської конкуренції неможливе без створення сучасної матеріально-технічної та науково-дослідної бази на основі інформаційно-комунікаційних технологій.

\section{Література}

1. Першочергові сфери, ініціативи, проекти «цифровізації» України до 2020 року. URL: https:// drive.google.com/drive/ folders/0B8Oa6Q2z KDSN2Q2MnNJd1NXa0U/ (дата звернення 22.10.2019).

2. Стандарт вищої освіти за спеціальністю 221 «Стоматологія». URL: https://mon.gov.ua/storage/app/media/vishcha-osvita/ zatverdzeni\%20standarty/2019/06/25/221-stomatologiya-magistr.pdf (дата звернення 22.10.2019).

3. Навчальний центр Аполонія. URL: https://www.radlinsky.com.ua/(дата звернення 22.10.2019).

4. Computer-aided design and manufacturing and rapid prototyped nanoscale hydroxyapatite/polyamide (n-HA/PA) construction for condylar defect caused by mandibular angle ostectomy / J. Li, Y. Hsu, E. Luo et al. // J. Aesthetic Plast. Surg, 2011 Aug. Vol. 35 (4). P. 636-640.

5. Артьоменко В. В., Семченко С. С. Симуляційне навчання в медицині: міжнародний та вітчизняний досвід // Одеський медичний журнал. 2015. № 6. С. 67-74.

6. Лісовий В. М., Капустник В. А. та ін. Загальні проблеми та перспективи застосування симуляційних методів освіти. Симуляційне навчання в системі підготовки медичних кадрів : матеріали навч.-метод. конф., присвяченої 212-й річниці від дня заснування ХНМУ. Харків : ХНМУ, 2016. 188 с. 